\title{
CHLOROPLAST DIVISION DURING LEAF DEVELOPMENT OF XANTHIUM PENSYLVANICUM WALLR. (COMPOSITAE)
}

\author{
ROMAN MAKSYMOWYCH ${ }^{1}$, NORMAN DOLLAHON, RUSSELL J. WILLIAMS, JOSEPH A.J. ORKWISZEWSKI \\ ${ }^{1}$ Biology Department, Villanova University, Villanova, PA 19085
}

(Received: August 24, 1998. Accepted: February 12, 1999)

\begin{abstract}
Division and growth of chloroplasts was studied during leaf development of Xanthium pensylvanicum at various stages of development represented by the leaf plastochron index.

Between leaf plastochron indices -1.00 and 2.56 chloroplast division was observed with little enlargement. Between 2.50 and 5.00 chloroplasts enlarged in diameter with an average rate of $0.21 \mu \mathrm{m}$ per day. At leaf plastochron index 5.00 chloroplasts attained their mature size of $6.12 \mu \mathrm{m}$. No chloroplast division was found after leaf plastochron index 2.50 . A change in shape of plastids from spherical proplastids to discoidal accompanied their growth during stages 2.50 and 5.00.
\end{abstract}

KEY WORDS: Xanthium pensylvanicum, chloroplast, leaf plastochron index, chloroplast growth.

\section{INTRODUCTION}

Developmental processes, such as leaf elongation, epidermal and palisade growth, expansion of lamina surface, relative elemental rates of lamina growth and other aspects, have been investigated as a function of the leaf plastochron index (Maksymowych 1990). However, chloroplast growth and division in Xanthium have not been investigated. The purpose of this investigation is to determine developmental stages of Xanthium leaves at which chloroplast division occurs.

\section{MATERIALS AND METHODS}

Burs of Xanthium pensvlvanicum were germinated in flats of soil in the greenhouse. After the first two foliage leaves had developed, seedlings were transplanted into $15 \mathrm{~cm}$ clay pots. The plants were grown in a growth chamber with constant temperature of $25 \pm 1^{\circ} \mathrm{C}$. Illumination consisted of a mixture of incandescent and fluorescent bulbs and was cycled over $24 \mathrm{~h}$ to give an $18 \mathrm{~h}$ light period to insure vegetative growth. Morphological ages of plants were determined by the leaf plastochron index (LPI) (Erickson and Michelini 1957).

Transmission Electron Microscopy (TEM) - Portions of lamina tissues were excised from the blade at the midpoint between the tip and the base and fixed in 5\% glutaraldehyde in $0.08 \mathrm{M} \mathrm{NaOH}$-PIPES (piperazine $\mathrm{N}-\mathrm{N}^{\prime}$ bis-2 ethanol sulfonic acid) buffer $\mathrm{pH} 6.8$ overnight at $4^{\circ} \mathrm{C}$ (modified from Salema and Brandao 1973). Tissues were rinsed in 0.2M NaOH-PIPES pH 6.8 , then post fixed in $2 \%$ osmiumn tetroxide in $0.2 \mathrm{M} \mathrm{NaOH}$-PIPES pH 6.8 for one hour at room temperature. Unreacted Osmium tetroxide was removed with several buffer rinses followed by deionized water washes. Acetone was used to dehydrate the tissues through a graded series prior to infiltration with Spurr resin (Electron Microscopy Sciences, Fort Washington, PA). Tissue blocks were polymerized in an oven over 24 hours at $70^{\circ} \mathrm{C}$.

Ultramicrotomy - Following polymerization tissue blocks were sectioned on a RMC $6000-\mathrm{XL}$ ultramicrotome to a thickness of 60-90 nm using a diamond knife and collected on 300 mesh copper grids, stained with $2 \%$ Uranyl acetate and Reynolds Lead citrate then examined and photographed on a Hitachi H600 TEM at an accelerating voltage of $75 \mathrm{Kv}$.

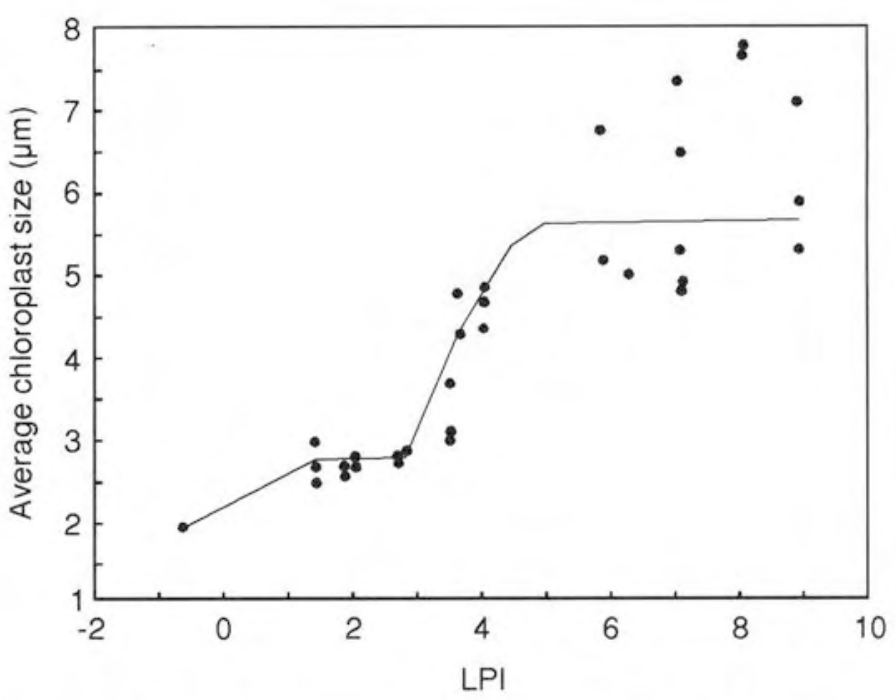

Fig. 1. Average chloroplast size plotted against leaf plastochron index (LPI). Chloroplast division was observed during the lag period between LPIs -1.0 and 2.5. Growth phase was between LPIs 2.5 and 5. Mature chloroplasts were found after LPI 5.0. 

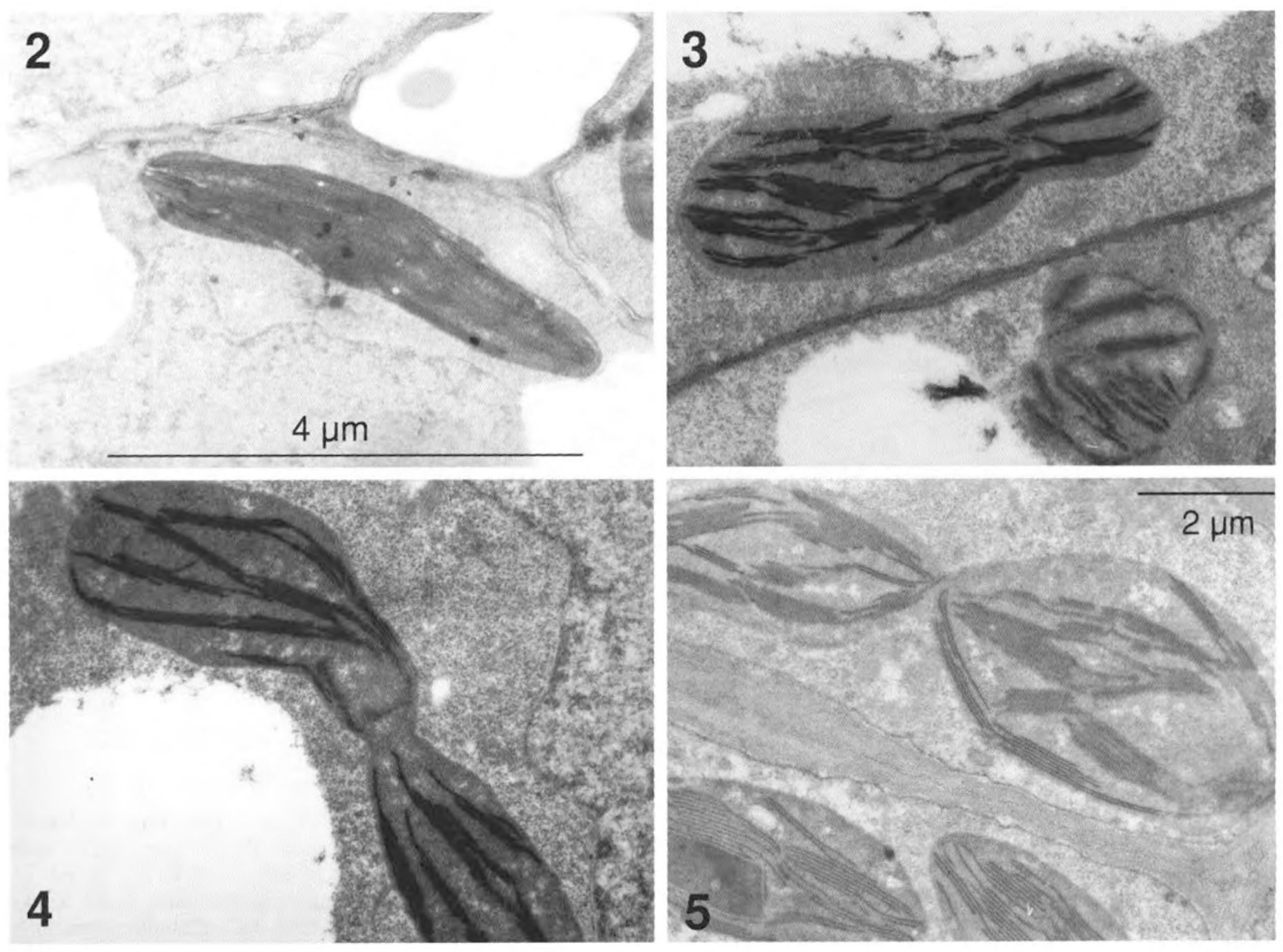

Figs 2-5. Transmission electron micrograph with various stages of dividing chloroplasts, LPI range was from -1.0 to 2.0. Magnification scale of Fig. 2 refers also to Figs 3 and 4 .

Chloroplast size was determined from photographic prints of electron microscopic sections similar to the method of Holowinsky, et al. (1965). As reported by many authors (Linsbauer 1962; Esau 1965; Clowes and Juniper 1968 and others) mature chloroplasts appear as discoid structures, roughly 6 $\mu \mathrm{m}$ in diameter and $3 \mu \mathrm{m}$ thick. This would indicate that peripheral sections of the discs would be small in size. Only largest dimensions of chloroplast sections were measured.

The variability of mature chloroplast size was expressed by $95 \%$ confidence limits and was $6.12 \pm 0.186 \mu \mathrm{m}$. The average thickness of chloroplasts was $1.84 \pm 0.184 \mu \mathrm{m}$.

\section{RESULTS}

The average size of chloroplasts was plotted against LPI in Fig. 1. The curve was fitted over the average values calculated at one plastochron intervals. There is a protracted lag period between LPIs -1.0 and 2.5. Chloroplast divisions (Figs 2-5) were observed during this lag period with negligible increase in size of individuals. Between LPIs 2.5 and 5.0 chloroplasts grew in size, reaching a mature size of $6.12 \mu \mathrm{m}$ after LPI 5.0.
The rate of enlargement during the phase of rapid growth was $0.516 \mu \mathrm{m}$ per plastochron or $0.21 \mu \mathrm{m}$ per day.

\section{DISCUSSION}

Clowes and Juniper (1968) gave an average larger diameter of discoid shaped chloroplasts size of $5 \times 2 \mu \mathrm{m}$ and Esau (1965) listed $6 \times 4 \mu \mathrm{m}$. Linsbauer (1962) listed $5 \mu \mathrm{m}$ as the average larger diameter of discoid shaped chloroplasts. Holowinsky et al. (1965) studied chloroplast size in Xanthium leaves. Mature chloroplast size was $6 \mu \mathrm{m}$. Our measurement of $6.12 \mu \mathrm{m}$ appear in agreement with the above quoted dimension. Ueda and Wada (1964) gave a range of 15-50 chloroplasts per mesophyll cell. Esau (1965) listed an average of 76 chloroplasts per palisade cell and 24 in spongy mesophyll cells.

There appears to be good correlation between the cell division phase (Maksymowych 1990) and chloroplast division. Cell division during leaf development stopped at 3 LPI and chloroplast division after 2.5 LPI. 
Meristamatic cells of lamina at negative LPIs show spherical bodies of immature proplastids (Maksymowych 1990). Apparently chloroplast division appears to be synchronized with the phase of cell division during Xanthium leaf development.

\section{LITERATURE CITED}

ERICKSON R.O., MICHELINI F.J. 1957. The plastochron index. Amer. J. Bot. 44: 297-305.

ESAU K. 1965. Plant anatomy, 2nd ed., John Wiley and Sons Inc., New York. Clowes F.A.L., Juniper B.E. 1968. Plant Cells. 546 pp. Blackwell Scientific Publications, Oxford.
HOLOWINSKY A.W., MOORE P.B., TORREY J.G. 1965. Regulatory aspects of chloroplast growth in leaves of Xanthium pensylvanicum and etiolated red kindey bean seedling leaves. Protoplasma 60: 94-110.

LINSBAUER K. 1962. Handbuch der Pflanzenanatomie, 2nd edn, 461 pp. Gebruder Borntrager, Berlin-Nikolassee.

MAKSYMOWYCH R. 1990. Analysis of growth and development of Xanthium. Cambridge University Press.

SALEMA R., BRANDAO I. 1973. The use of PIPES buffer in fixation of plant cells for electron microscopy. J. Sub. Cytol. 5: 79-96.

UEDA R., WADA M. 1964. Structure and development of the plastids in leaf epidermis. Scientific Report Tokyo yoiku Diagaku 10: 95110 .

\section{PODZIAŁY CHLOROPLASTÓW \\ PODCZAS ROZWOJU LIŚCIA U XANTHIUM PENSYLVANICUM WALLR. (COMPOSITAE)}

\section{STRESZCZENIE}

Podział chloroplastów badano w różnych stadiach rozwoju liścia Xanthium pensylvanicum określanych wskaźnikiem plastochronowym. Dla wartości wskaźnika od $-1,00$ do 2,56 obserwowano podział chloroplastów z nieznacznym powiększaniem ich rozmiarów. Pomiędzy 2,50 a 5,00 chloroplasty zwiększały swoją średnic z przeciętną szybkością wynoszącą $0,21 \mu \mathrm{m}$ dziennie. Przy wskaźniku plastochronowym liścia wynoszącym 5,00 chloroplasty osiągały swoje ostateczne wymiary wynoszące $6,12 \mu \mathrm{m}$. Nie stwierdzono podziału chloroplastów powyżej wartości wskaźnika 2,00. Zmiana kształtu plastydów ze sferycznego w płaski miała miejsce przy wartościach wskaźnika 2,50-5,00.

SŁOWA KLUCZOWE: Xanthium pensylvanicum, chloroplast, wskaźnik plastochronowy liścia, rozwój chloroplastów. 